\title{
Phytoremediation of Heavy Metal Contaminated Soil by Psoralea Pinnata
}

\author{
Richie O. Ochonogor and Harrison I. Atagana, Member, CBEES
}

\begin{abstract}
Soil contaminated with iron and chromium was planted with Psoralea pinnata under greenhouse condition. The growth of the plants and phytoextraction of the metal contaminants from the soil were studied for a period of three months. The results showed that Psoralea pinnata was able remove both chromium and iron from the contaminated soil during the period of experimentation. The percentage reduction in chromium and iron concentrations in the experimental soil varied greatly at different concentration of both contaminants in the two soils used. It was observed however that at some points in the experiment involving mixed concentration of iron and chromium, there were preferences on accumulation of metals by Psoralea pinnata. Results show that chromium was initially most accumulated by Psoralea pinnata (up to $68 \%$ ). As the concentration of contaminants increased, at high concentrations, iron was recorded to have been accumulated more in Psoralea pinnata (up to 55\%).
\end{abstract}

Index Terms-Chromium, iron, phytoextraction, Psoralea pinnata.

\section{INTRODUCTION}

Soils contamination by heavy metals and metalloids has become a serious environmental issue today. A number of metals including chromium, iron, arsenic, zinc, cadmium, mercury and copper are known to significantly compromise the quality of soil and cause adverse effects to human and health and the well being of other organisms that comes in contact with such soil. Heavy metals are extremely persistent in the environment because they are not biodegradable and may not be broken down by chemical oxidation [1] or through thermal processes, as a result their accumulation readily reaches to toxic levels [2]. Some metals are essential for plant growth however, very high or low concentrations of some these heavy metals may be inhibitory to plant growth. Human activities such as metal smelting, electroplating and mining are sources through which heavy metals enter the environment. According to Kuhndt [3], about 100-350 tons of residues are generated during the extraction processes for every ton of copper produced. South Africa has about $70 \%$ of the world's chrome reserve and is the world's largest producer of ferrochrome $(75 \%)$. South Africa has about 6000 abandoned mines most of which have potential to contaminate the environment [4]. The contamination of soil

Manuscript received November 8, 2013; revised February 17, 2014.

R. O. Ochonogor is with the Department of Environmental Sciences, University of South Africa, P.O. Box 392, Pretoria 0003, South Africa.

H. I. Atagana is with the Institute for Science and Technology Education, University of South Africa, P.O. Box 392, Pretoria 0003, South Africa (e-mail: atagahi@unisa.ac.za). with heavy metals in each of the sites is dependent on length of operation of mines. Rain and runoff waters help to increase the chance of extending metal contamination beyond the primary contaminated sites. Metals have the potential to accumulate in human body when contaminated plants are ingested and may produce unwanted side effects [5]-[7]. Methods used for remediation of heavy metal contaminated soil include soil flushing, solidification/stabilization, vitrification, thermal desorption and encapsulation [8]. Other methods include burying of the contaminated soil or dilution of the contaminated soil with clean soil. These methods contribute to long-term risks such as leaching into groundwater and surrounding soil [1].

Due to the expensive nature of the conventional remediation methods for heavy metal contamination [9], phytoremediation technologies are continuously being researched for possible solutions. The level of heavy and toxic metals $(\mathrm{Pb}, \mathrm{Cr}, \mathrm{Hg}$, etc.) in the environment can be reduced from contaminated sites or media using a number of aquatic and terrestrial plants. Metals are taken up in solution by the root system of plants and transported to the stems and leaves without showing toxicity syndromes and this have been supported by many studies [10], [11]. As a developing technology [12], phytoremedaition, particularly phytoextraction have been applied to metals contaminations containing (e.g. $\mathrm{Ag}, \mathrm{Cr}, \mathrm{Fe}, \mathrm{Cu}, \mathrm{Hg}, \mathrm{Mn}, \mathrm{Mo} \mathrm{Ni}, \mathrm{Pb}, \mathrm{Zn}$ ), metalloids (e.g. As, Se), radionuclides (e.g. 90Sr, 137Cs, 234U, 238U) and non-metals [13], [14]. Phytoextraction employs plants to transport and accumulate high quantities of metals from soil into the harvestable parts of roots and above ground shoots [15], [16], and has emerged as a cost effective, environmentally friendly clean up alternative [17]. The phytoextraction or hyperaccumulation of metals in various plant species have been extensively investigated and substantial progress has been made. The potential of duck weed was investigated by Zayed et al. [18] for the removal of $\mathrm{Cd}, \mathrm{Cr}$, and $\mathrm{Cu}$ from nutrient-added solution and the results indicated that duck weed is a good accumulator for $\mathrm{Cd}$ and $\mathrm{Cu}$, but his result was unable to establish potential plant for abstracting $\mathrm{Cr}$ from the soil. Brooks, [19] investigated the uptake of $\mathrm{Cr}$ from soil by the use of some plants including Indian mustard (Brassica juncea). He indicated that there is no evidence of $\mathrm{Cr}$ hyperaccumulation by any vascular plants. Robinson et al. [20] investigated the potential of Berkheya Coddii to phytoextract Co from artificial metalliferous media. Although, Co was readily taken up by the plant, cobalt was toxic to the plant above a certain limit. Although, majority of phytoextraction investigations have focused on $\mathrm{Cd}, \mathrm{Pb}$ and $\mathrm{Zn}$ [21], Fe contamination is a more prominent problem in many soils particularly where iron extraction is common and 
where conversion of iron into various kinds of steel carried out.

The hyperaccumulators that have been extensively studied includes Thlaspi spp., Arabidopsis spp., sedum alfredii spp., belonging to the families Brassicaceae and Alyssum [22]. Psoralea pinnata belongs to the family Fabaceae thriving well in both wetland and upland habitats. The use of Psoralea pinnata in phytoextraction has not been investigated. The aim of this study is to investigate the use of Psoralea pinnata in phytoextracting $\mathrm{Fe}$ and $\mathrm{Cr}$ from contaminated soil under green house conditions.

\section{Materials AND Methods}

\section{A. Plant}

Psoralea pinnata, seeds were collected from Silver Hills Seeds and Brook, Cape Town. The seeds were planted and watered in a green house for four weeks. Healthy plants with a height of about $11.50 \mathrm{~cm}$ were selected for the phytoextraction experiments.

\section{B. Treatments}

TABLE I: CHARACTERISTICS OF THE SOIL USED IN THE EXPERIMENTS

\begin{tabular}{|c|c|c|}
\hline 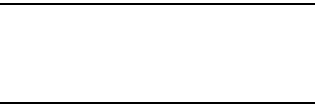 & Garden soil & $\begin{array}{l}\text { Commercial } \\
\text { Potting Soil }\end{array}$ \\
\hline pH-H ${ }_{2} \mathrm{O}$ & $7.41 \pm 0.25$ & $6.43 \pm 0.49$ \\
\hline CEC (meq/100g soil) & 11.2 & 21.8 \\
\hline Organic carbon $((\%$ wt $))$ & 12.12 & 0.87 \\
\hline $\mathrm{N}_{\text {tot }}(\% \mathrm{wt})$ & 0.02 & 0.05 \\
\hline $\mathbf{P}_{\text {tot }}(\% \mathrm{wt})$ & 4.4 & 9.1 \\
\hline $\mathrm{K}(\mathbf{p p m})$ & $3.2 \pm 0.29$ & $14.8 \pm 0.52$ \\
\hline Sand $(\%)$ & 63.9 & 8.9 \\
\hline Silt (\% wt) & 15.3 & 18.0 \\
\hline Gravel (\% wt) & $\leq 5$ & N/A \\
\hline Clay $(\%$ wt) & 19.0 & 69.8 \\
\hline Ca (ppm) & $61.5 \pm 0.39$ & $82.8 \pm 0.53$ \\
\hline $\mathrm{Mg}_{\text {tot }}(\mathrm{ppm})$ & $1.5 \pm 0.79$ & $8.5 \pm 0.82$ \\
\hline Mn (ppm) & $9.7 \pm 0.89$ & $75.6 \pm 0.64$ \\
\hline $\mathrm{Na}(\mathrm{ppm})$ & $147 \pm 0.03$ & $44.0 \pm 0.61$ \\
\hline $\mathrm{Fe}_{\text {tot }}(\mathbf{p p m})$ & $57.2 \pm 0.61$ & $4.6 \pm 0.45$ \\
\hline $\mathrm{Cr}_{\text {tot }}(\mathbf{p p m})$ & $78.0 \pm 0.27$ & $10.2 \pm 0.31$ \\
\hline
\end{tabular}

The two soils types were separately mixed with compost in a ratio of 5:1 (w/w) (soil: compost) (see Table I). Eight experiments were set up in triplicates in PVC pots $(550 \times 413 \mathrm{~mm})$ by contaminating each soil with a $1.5: 1$ ratio (v/v) of $\mathrm{Cr}\left(\mathrm{KCrO}_{4}\right)$ and $\mathrm{Fe}\left(\mathrm{Fe}\left(\mathrm{NO}_{3}\right)_{3} \cdot 9 \mathrm{H}_{2} \mathrm{O}\right)$ to mimic the composition of both metals in a typical ferrochrome. The combined total concentration of both metals in the treatments ranged from 40 to $320 \mathrm{mg} \mathrm{kg}^{-1}$. The treatments for both soil types contained $\mathrm{Cr}$ and $\mathrm{Fe}$ in $\mathrm{mg} \mathrm{kg}^{-1}$ as follows:

$\mathrm{T}_{40}=24 \mathrm{Cr}+16 \mathrm{Fe}, \mathrm{T}_{80}=48 \mathrm{Cr}+32 \mathrm{Fe}, \mathrm{T}_{120}=72 \mathrm{Cr}+48$ $\mathrm{Fe}, \mathrm{T}_{160}=96 \mathrm{Cr}+64 \mathrm{Fe}, \mathrm{T}_{200}=120 \mathrm{Cr}+80 \mathrm{Fe}, \mathrm{T}_{240}=144 \mathrm{Cr}$ $+96 \mathrm{Fe}, \mathrm{T}_{280}=168 \mathrm{Cr}+112 \mathrm{Fe}, \mathrm{T}_{320}=192 \mathrm{Cr}+128 \mathrm{Fe}$

Two sets of control experiments were separately set up using the garden soil and commercial potting soil without metals. Four week old Psorelea pinnata plants from the nursery were transplanted into the contaminated soils and the controls and allowed to grow for 3 months in the green house. Moisture was kept at $60-70 \%$ field capacity. Leaching was avoided by adding only a little amount of the water at a time.

Plants were harvested after 3 months growth, washed, dried and homogenised before digesting $15 \mathrm{~g}$ in a mixture of $\mathrm{HNO}_{3}: \mathrm{HCl}(1: 3)$ and analyzing in Atomic Absorption Spectrophotometer (AAS)

Ten grams of soil samples were digested in an acid mixture of $\mathrm{HNO}_{3}: \mathrm{HCl}(1: 3)$. The chromium and iron content of the samples were analyzed using Atomic Absorption Spectrophotometer (AAS).

\section{RESULTS AND DISCUSSION}

The result of the analysis of the two soils are shown in Table 1. Most measured parameters including organic carbon varied considerably in both soils. The results of analysis for $\mathrm{Cr}$ and $\mathrm{Fe}$ in plant tissues from the experimental plants shows that the plant tissues accumulated between 12 and $27 \% \mathrm{Cr}$ and 18 and $22 \% \mathrm{Fe}$ of the amount of $\mathrm{Cr}$ and $\mathrm{Fe}$ present in the garden soil. The largest amounts $(\%)$ accumulated were in $\mathrm{T}_{40}$ (27), $\mathrm{T}_{80}$ (20) and $\mathrm{T}_{120}(20.5)$ for $\mathrm{Cr}$ (see Fig. 1) and $\mathrm{T}_{40}$ (20.5), $\mathrm{T}_{160}(21)$ and $\mathrm{T}_{200}$ (22) for Fe (see Fig. 2).

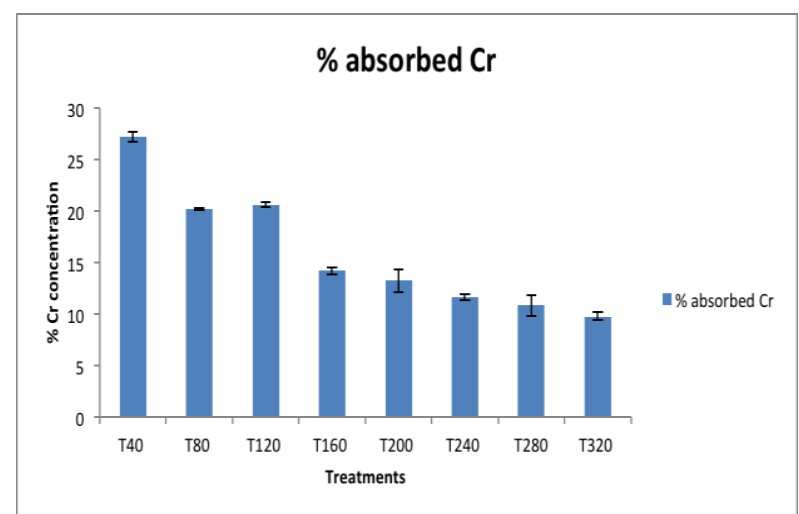

Fig. 1. Amount of $\mathrm{Cr}$ accumulated in plant tissues (\% of soil concentration) in garden soil. Values are means of $3+/-\mathrm{SE}$.

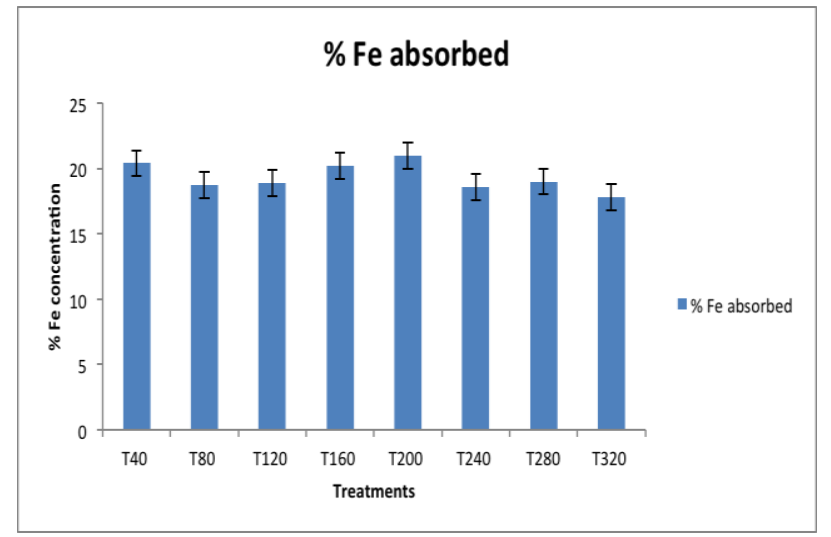

Fig. 2. Amount of $\mathrm{Fe}$ accumulated in plant tissues (\% of soil concentration) in garden soil. Values are means of $3+/-\mathrm{SE}$.

Both metals were taken up well by the experimental plants. The difference in the concentration of Fe between $\mathrm{T}_{40}$ and $\mathrm{T}_{320}$ in the mixed contamination in the garden soil did not significantly affect the rate of accumulation of Fe in the plant 
tissues. However, the rates of accumulation of $\mathrm{Cr}$ was significantly affected by the increases in concentrat. Although all plants grew well in the soil, leaf yellowing was observed in some of the plants in $\mathrm{T}_{240}-\mathrm{T}_{320}$.

Generally, there tended to be a decrease in the amount of both metals accumulated as concentration of metals increased. This is an indication of toxicicty at elevated concentrations, however, it could not determined which of the metals was responsible for the toxic effect or whether the effect was due to both metals.

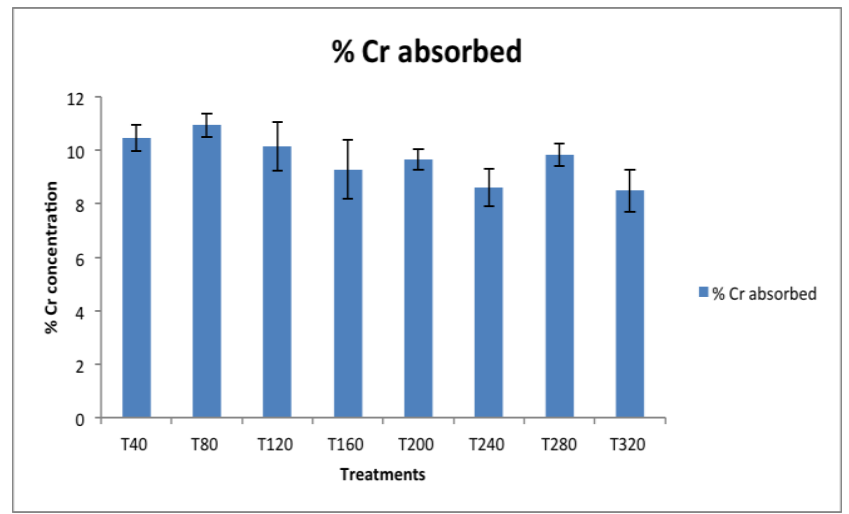

Fig. 3. Amount of $\mathrm{Cr}$ accumulated in plant tissues (\% of soil concentration) in commercial potting soil. Values are means of $3+/-\mathrm{SE}$.

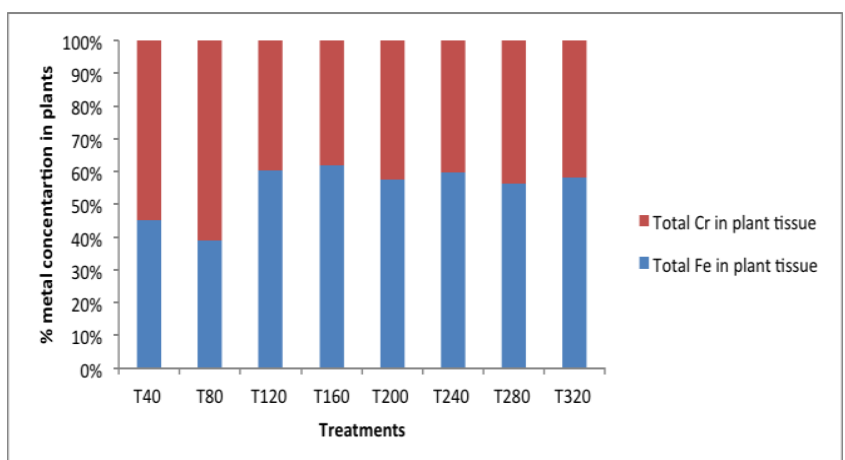

Fig. 4. A comparison of the amounts of $\mathrm{Cr}$ and $\mathrm{Fe}$ accumulated in plant tissues in garden soil. Values are means of $3+/-$ SE.

Changes in metal concentration did not significantly affect the rate of accumulation of $\mathrm{Cr}$ in the commercial potting soil (see Fig. 3). The difference in the responses to concentration of the metals could not be readilly explained. However, there were a number of differences in both chemical and physical parameters of the two soils. The cation exchange capacity and (CEC) and the organic carborn are to parameters that could be responsible for the difference. From Treatments T40 to $\mathrm{T} 160, \mathrm{Cr}$ was the dominant metals accumulated by Psoralea pinnata in preference to Fe. In the Treatment T200, there was no significant difference between the accumulation of $\mathrm{Cr}$ and $\mathrm{Fe}$ although the accumulation of $\mathrm{Fe}$ was slightly higher (see Fig. 4). The treatment with the most iron absorption in relation to chromium absorption is T320. It was observed that with rising concentration of metals in the soil, Psoralea pinnata absorbed more of Fe than of $\mathrm{Cr}$.

The results show that plants in the control experiments with garden soil and commercial potting soil showed a very low amounts of both metals. The total amounts of $\mathrm{Fe}$ accumulated in the garden soil $6.34 \%$ and $1.38 \%$ in the commercial potting soil. The total amounts of $\mathrm{Cr}$ accumulated in the garden soil was $3.48 \%$ and $3.11 \%$ in the commercial potting soil. These results are not unexpected, as the control experiments were not spiked with $\mathrm{Fe}$ and $\mathrm{Cr}$ and the concentrations of both metals in the soil were very low (see Table I).

These results support those of previous studies where it was observed that there was competition between $\mathrm{Cr}$ and other metals for binding sites. Sharma and Pant, [23], showed that in maize plants, the effects of $\mathrm{Cr}$ on $\mathrm{Fe}$ concentration varied with plant organs and also with $\mathrm{Cr}$ levels. They observed that $\mathrm{Mn}, \mathrm{Fe}$ and $\mathrm{Cu}$ concentrations generally decreased with increase in Cr levels. In a study on $\mathrm{Cr}$ (III)-Fe interaction, Bonet et al. [24] reported that $\mathrm{Cr}$ enhanced growth of both Fe-controled and Fe-deficient plants. However, $\mathrm{Cr}$ concentrations correlated neither with changes of $\mathrm{Mn}, \mathrm{P}$ nor $\mathrm{Fe}$ tissue concentrations or $\mathrm{Cr}$-induced alterations of the $\mathrm{Fe} / \mathrm{Mn}$ and $\mathrm{P} / \mathrm{Fe}$ ratios. The reduction in the uptake of Fe could be mainly due to the chemical similarity of $\mathrm{Fe}$ and $\mathrm{Cr}$ ions in solution. Hence, the competitive binding to common carriers by $\mathrm{Cr}(\mathrm{VI})$ could have reduced the uptake of many nutrients [25].

\section{CONCLUSION}

From the results obtained in this study, Psorelea piñata has demonstrated that it can accumulate $\mathrm{Fe}$ and $\mathrm{Cr}$ in contaminated soils under green house conditions. It has also shown that it can tolerate high levels of metal contamination with minimal inhibition in growth processes. It would therefore be a useful plant to test further for hyperaccumulation of toxic heavy metals.

\section{REFERENCES}

[1] A. N. Matthew, "Phytoremediation of heavy metal contaminated soil," MSc dissertation, Graduate College, Oklahoma State Univ., Tulsa, Ok, 2005.

[2] H. L. Bohn, B. L. McNeal, and G. A. O'Connor, Soil Chemistry, 2nd ed. New York: Wiley, 1985, pp. 50-55.

[3] M. Kuhndt, J. Von Geibler, V. Türk, S. Moll, K. O. Schallaböck, and S Steger. (May 2012). Virtual dematerialisation: ebusiness and factor X Wuppertal Institute Final Report. Digital Europe, March. [Online]. Available:

http://www.itktb.hu/resource.aspx?ResourceID=dematerial_report

[4] Times Live. (April 23, 2012). [Online]. Available: http://www.timeslive.co.za'

[5] L. Jarup. "Hazards of heavy metals contamination," Br. Med. Bull., vol. 68, pp. 167-182, May 2003.

[6] N. G. Sathawara, D. J. Parikh, and Y. K. Agarwal. "Essential heavy metals in environmental samples from western India,"Bull. Environ. Contam. Toxicol., vol. 73, pp. 756-761, September 2004.

[7] S. Ata, F. Moore, and S. Modabberi, "Heavy metal contamination and distribution in the Shiraz industrial complex zone soil, South Shiraz," Iran. World. App. Sci. J., vol. 6, no. 3, pp. 413-425, June 2009.

[8] BIO-WISE, "Contaminated Land remediation: A review of biological technology," London DTI., 2003.

[9] L. T. Danh, P. Truong, R. Mammucari, T. Tran, and N. Foster. "Vetiver grass, Vetiveria zizanioides: A choice plant for phytoremediation of heavy metals and organic wastes," Int. J. Phytorem, vol. 11, pp. 664-691, August 2009.

[10] A. J. Cardwell, D. W. Hawker, and M. Greenway, "Metal accumulation in aquatic macrophytes from southeast Queensland, Australia," Chemosphere, vol. 48, pp. 653-663, 2002.

[11] J. Chatterjee and C. Chatterjee, "Phytotoxicity of cobalt, chromium and copper in cauliflower," Enviro.n Pollut., vol. 109, pp. 69-74. 2000.

[12] Z.-L. He, Y.-D. Jing, and X.-E Yang, "Role of soil rhizobacteria in phytoremediation of heavy metal contaminated soils," J. Zhejiang Univ. Sci. B, vol. 8, no. 3, pp. 192-207, 2007. 
[13] D. E. Salt, M. Blaylock, B. A. Kumar, V. Dushenkov, I. Chet, and I. Raskin, "Phytoremediation: a noval strategy for the removal of toxic metals from the environment using plants," Biotechnology, vol. 13, pp. 468-474. 1995

[14] J. Cornish, S. D. Ebbs, M. M. Lasat, D. J. Brandy, R. Gordon, and L. V. Kochian, "Heavy metals in the environment: Phytoextraction of cadmium and zinc from a contaminated soil," J. Environ. Quality, vol. 26, pp. 1424-1430. 1997.

[15] R. L. Chaney, "Plant uptake of inorganic waste constitutes," in Land Treatment of Hazardous Wastes, J. F. Parr, P. B. Marsh, and J. M. Kla, Eds. NJ: Park Ridge, Noyes Data Corp., 1993, pp. 50-76.

[16] R. L. Chaney, M. Malik, Y. M. Li, S. L. Brown, E. P. Brewer, J. S Angle, and A. J. M Baker, "Phytoremediation of soil metals," Current Opinions in Biotechnology, vol. 8, no. 3, p. 279, 1997.

[17] F. Itanna and B. Coulman, "Phyto-extraction of copper, iron, manganese, and zincfrom environmentally contaminated sites in Ethiopia, with three grass species," Communication in Soil Science and Plant Analysis, vol. 34, no. 1\&2, pp. 111-124, 2003.

[18] A. M. Zayed and N. Terry, "Selenium volatilization by plants," in Selenium in the Environment, W. T. Frankenberger Jr. and S. Benson, Eds. New York: Marcel Dekker, 1998, pp. 343-369.

[19] R. R. Brooks and B. H. Robinson, "Aquatic phytoremediation by accumulator plants," in Plants that Hyperaccumulate Heavy Metals: Their Role in Phytoremediation, Microbiology, Archaeology, Mineral Exploration and Phytomining, CAB International, Oxon, UK, 1998, pp. 203-226.

[20] B. H. Robinson, M. Leblanc. and D. Petit, "The potential of Thlaspi caerulescens for phytoremediation of contaminated soils," Plant Soil, vol. 203, no. 1, pp. 47-56, 1998.

[21] J. W. Huang, J. Chen, W. R. Berti et al., "Phytoremediation of lead contaminated soil: role of synthetic chelates in lead phytoextraction," Environ. Sci. Technol., vol. 31, no. 3, pp. 800-805, 1997.
[22] M. N. V. Prasad and H. M. O. Freitas, "Metal hyperaccumulation in plants-Biodiversity prospecting for phytoremediation technology," Electronic J. Biotechnol, vol. 6, pp. 285-321, 2003.

[23] D. C. Sharma and R. C. Pant, "Chromium uptake its effects on certain plant nutrients in maize (Zea mays L. CV) Ganga," Journal of Environmental Science and Health, Part A, vol. 29, pp. 941-948, 1994.

[24] A. Bonet, C. Poschenrieder, and J. Barcelo. "Chromium III ion interaction in Fe deficient and $\mathrm{Fe}$ sufficient bean plants. I. Growth and Nutrient content," J. Plant Nutr., vol. 14, pp. 403-414, 1991.

[25] A. K. Shanker, "Physiological, biochemical and molecular aspects of chro-mium toxicity and tolerance in selected crops and tree species," PhD Thesis, Tamil Nadu Agricultural University, Coimbatore, India, 2003.

Richie O. Ochonogor has BSc in biochemistry and is currently studying towards the MSc degree in environmental management at the University of South Africa. The title of his MSc dissertation, which is currently being examined, is Phytoextraction of chromium and iron from contaminated soil using Psoralea pinnata. Richie hopes to continue studying towards the $\mathrm{PhD}$ degree in environmental management on completion of his MSc.

Harrison I. Atagana is a professor and the head of Institute for Science and Technology Education (ISTE), University of South Africa. His field of interests is in bioremediation, exotoxicology, phytoremediation, wasterwater treatment, freshwater quality, pollution studies, and science education. He is a rated researcher of the South African National Research Foundation and has held three research grants of the foundation. He has published extensively in peer reviewed international journals and has presented over twenty papers in at international and national conferences around the world. Professor Atagana currently has six masters and doctoral students in environmental biotechnology. 